Power Without

Responsibility 
This page intentionally left blank 


\section{POWER WITHOUT}

\section{RESPONSIBILITY}

\section{How Congress Abuses the \\ People Through Delegation}

David Schoenbrod

Yale University Press

New Haven and London 
Published with assistance from the Louis Stern Memorial Fund.

Copyright $\mathbb{C} 1993$ by Yale University.

All rights reserved.

This book may not be reproduced, in whole or in part, including illustrations, in any form (beyond that copying permitted by Sections 107 and 108 of the U.S. Copyright Law and except by reviewers for the public press), without written permission from the publishers.

Designed by James J. Johnson.

Set in Aster Roman type by Marathon Typography Service, Durham, North Carolina.

Printed in the United States of America

Library of Congress Cataloging-in-Publication Data Schoenbrod, David.

Power without responsibility : how Congress abuses the people through delegation / David Schoenbrod.

p. $\mathrm{cm}$.

Includes bibliographical references and index. ISBN 978-0-300-06518-3

1. Delegated legislation-United States.

2. Administrative procedure-United States.

3. United States. Congress-Powers and duties.

I. Title.

KF5411.S36 1993

342.73'066-dc20

[347.30266]

A catalogue record for this book is available from the British Library.

The paper in this book meets the guidelines for permanence and durability of the Committee on Production Guidelines for Book Longevity of the Council on Library Resources. 
To Frank Campbell

Kind teacher, kind friend 
This page intentionally left blank 